\title{
Metaphors about computer education of first year nursing students
}

\author{
Serap Çolak ${ }^{1 a}$, Dilşat Güzelordu ${ }^{2}$, Mehmet Deniz Yener ${ }^{2}$, Rabia Taşdemir $^{2}$, Arzu Topal $^{3}$, \\ Belgin Bamaç ${ }^{2}$, and Tuncay Çolak ${ }^{2}$ \\ ${ }^{1}$ Kocaeli University, School of Physical Education and Sport, Umuttepe, Kocaeli \\ ${ }^{2}$ Kocaeli University, Faculty of Medicine, Department of Anatomy, Umuttepe, Kocaeli \\ ${ }^{3}$ Kocaeli University, Department of Informatics, Umuttepe, Kocaeli
}

\begin{abstract}
The meaning of the word of metaphor is represented as likening indirect speech. A metaphor provides a more clear transfer about an idea encountered in an event, situation or a concept. The aim of this study was by the use of metaphor to learn the thoughts and feelings of nursing students about computer education. The study included 65 (45 female, 19 male ( 1 experimental subject has been excluded because of missing data)) nursing students of Kocaeli University (please note that gender wasn't specified on the first survey form). Students were asked by survey form to provide their age, gender, geographical region, place of residence within Kocaeli and their reason for choosing the department. We examined nursing students as opposed to computer education through the use of metaphors. Respondents filled in the blanks: "Computer education is similar to/like ... because...." 42 different metaphors were produced. Most of the metaphors produced pertained to the human brain, world, television, smart room, encyclopedia etc. When we separated them into categories and examined them, we see 18 metaphors in the category of guidance and investment in information. Nowadays the use of computers is very important in nursing just as it is in all job groups, particularly in their student life in operating Microsoft Office programs, Acrobat Reader and the like.
\end{abstract}

Keywords: Metaphor; computer; nursing; education.

\section{Introduction}

The word metaphor was derived from the Greek word 'metapherein' [9, 4]. The aim of this study was to learn the perceptions of nursing students about computer education using metaphor. Metaphor examinations are generally used in educational sciences $[3,7,8,5,2]$. Students of nursing will use computers in their work and daily lives. They will see benefits which minimize mistakes and increase speed and simplicity. Successful use of computers

\footnotetext{
${ }^{a}$ Corresponding author: srpclk@gmail.com
} 
and their interface software is necessary in student and work life. Programs such as Microsoft Office Suite and Acrobat Reader and other are most important. We aimed to learn the thoughts and feelings of first year nursing students about computer education via metaphor.

\section{Methods}

The method used in the study, the screening model method, reveals the perceptions the nursing students have about the concept of computer education through metaphors [4].

\subsection{Research Group}

65 (45 female, 19 male ( 1 experimental subject has been excluded because of missing data)) first year nursing students of Kocaeli University participated in the study (note that gender wasn't specified on the first survey form).

\subsection{Data Collection}

Students were asked by survey form to provide their age, gender, geographical region, place of residence within Kocaeli and their reason for choosing the department. We examined effect of demographic features on the computer education metaphors. Respondents filled in the blanks: "Computer education is similar to/like because " $\quad$ in order to produce metaphors about computer education from them. Students who joined voluntarily were included in our examination. 5 students out of the 65 did not provide a metaphor about computer education; they answered only the other questions. $46.15 \%$ of people who joined the survey specify to choose their department because of the possibility of finding a job. $61.53 \%$ came from Marmara. 42 different metaphors were produced. The number and percentages of metaphors produced were tallied by purpose in 6 separate categories [1]. Most of the metaphors produced pertained to the human brain, world, television, smart room, encyclopedia etc. When we separate them into categories, we see 18 metaphors in the category of guidance and investment in information. The category of exposure/exploration comes in second with 16 metaphors. The rest break down as follows: desperate fight 9, pain/pleasure 9, disappearance / unknown status 5, feeling of high / unhealthy pleasure 2, finding a solution to a problem 1 (Table-1).

\section{Results}

Table 1. The metaphor categories the nursing students have about the concept of computer education.

\begin{tabular}{cccc}
\hline Classification & Methaphor & $\begin{array}{c}\text { Frequency } \\
(\mathrm{F})\end{array}$ & $\begin{array}{c}\text { Percentage } \\
(\%)\end{array}$ \\
\hline 1.Unknown status & $\begin{array}{c}\text { Deserted island(1), } \\
\text { World(1),Philosophy(1), Corrupt } \\
\text { radio(1),Space(1) }\end{array}$ & 5 & $\% 8.33$ \\
& $\begin{array}{c}\text { Confusion(1), Youngest brother(1), } \\
\text { Puzzles(2), Ivy(1), White } \\
\text { 2.Hopeless fight } \\
\text { crayons(1), Egoist teacher(1), Open } \\
\text { umbrella in the snow(1), Curvy } \\
\text { roads(1) }\end{array}$ & 9 & $\% 15$ \\
& $\quad$ & & \\
\hline
\end{tabular}


Table 1. continued

3.Pain/Pleasure

Friends(1), Pickles(1),

Capitalism(1), World(1), Redundant

information(1), Nail Polish(1), $\quad 9 \quad \% 15$

Valentine(1), Opium

$\operatorname{syrup}(1)$, Television(1)

4.Find out,explore

Worker bees(1), The human body(3), World(1),Space(1),Sky(1),

Frame(1), Musical instruments(1),

The lifeblood of(1), Oxygen(1),

16

$\% 26,66$

Television(1), Freedom(1), The

spider(1),Brain(2)

\title{
5.Guidance, invest \\ ment in \\ information
}

\author{
Human(1), The human brain(9), \\ Practical artificial intelligence(1), \\ World(1), Robots(1), Dogs(1), \\ Information sea(1), Info box(1), \\ Encyclopedias (1), Smart Room (1) \\ $18 \quad \% 30$
}

\section{A finding \\ solutions to \\ problems}

Mathematics(1),

7.Pain
8. . Being drunk feeling / unhealthy pleasure
Smoking(1), Us to turn the machine robots(1),
$1 \quad \% 1,66$

0

0

$2 \quad \% 3,33$

\begin{tabular}{ccc}
\hline Total & 42 & $60^{*}$ \\
\hline
\end{tabular}

*5 students have not pointed out any metaphor

\section{Discussion and conclusion}

A metaphor is generally defined as describing a phenomenon or a concept in more familiar terms [2]. Although the usage of metaphors as pedagogical tools is a recent development, using them as a teaching tool has been common for a very long time [2]. Various studies on education have been done on university students [4, 6]. Colak [4] used metaphors to elicit the thoughts of physical education and sports medicine students on computer training. As we mentioned, students who joined our study wrote metaphors related to the category of guidance/investment in information. This demonstrates how valued computers are by nursing students both in learning their health practices and when applied in their job. Nowadays computers are very important in nursing as in all job groups. Because of this we believe the metaphors written by students will guide us in computer education. 


\section{References}

1. Aktekin, M., \& Aktekin, N.C., Anatomi öğrenmenin kacınılmaz acısı. XIIIth National Congress of Anatomy with International participation, Kyrenia, Turkish Republic of Northern Cyprus, 28th October-1st November, 2, (2010).

2. Arslan, M.M., \& Bayrakcı, M., Metaforik düşünme ve öğrenme yaklaşımının EğitimÖğretim açısından incelenmesi. Milli Eğitim, 35(171), 100-108, (2006).

3. Botha, E., Why metaphor matters in education. South African Journal of Education. 29, 431-444, (2009).

4. Colak, S., Metaphoric perceptions of school of physical education and sport students to the concept "computers education". Procedia-Social and Behavioral Science, 174, 3210-3213, (2015).

5. Güveli, E., İpek, S., Atasoy, E., \& Güveli, H., Sınıf öğretmeni adaylarının matematik kavramına yönelik metafor algiları. Turkish Journal of Computer and Mathematics Education, 2(2), 140-159, (2011).

6. Kalyoncu, R., Visual arts teacher candidates metaphors related to concept of teaching. Mustafa Kemal University Journal of Social Sciences Institute. 9(20), 474-484, (2012).

7. Saban, A., Giriş düzeyindeki sınıf öğretmeni adaylarının öğretmen kavramına ilişkin ileri sürdükleri metaforlar. Türk Eğitim Bilimleri Dergisi. 2(2), 131-155, (2004).

8. Sevim, O., Veyis, F., \& Kınay N., Öğretmen adaylarının türkçeyle ilgili algılarının metaforlar yoluyla belirlenmesi: atatürk üniversitesi örneği. Cumhuriyet International Journal of Education, 1(1), 38-47, (2012).

9. Soysal, D., \& Afacan, O., Metaphors used by primary school students to describe 'Science and technology lesson' and 'Science and technology teacher'. Mustafa Kemal University Journal of Social Sciences Institute, 9(19), 287-306, (2012). 